\title{
ПОРІВНЯЛЬНИЙ АНАЛІЗ ПОКАЗНИКІВ ЦЕНТРАЛЬНОЇ ГЕМОДИНАМІКИ У СПОРТСМЕНІВ-ДЗЮДОЇСТІВ ВИСОКОЇ КВАЛІФІКАЦІЇ В ЗАЛЕЖНОСТІ ВІД ВІКУ, КВАЛІФІКАЦІЇ ТА СТАЖУ ЗАНЯТЬ
}

\section{І. М. Олексенко}

\author{
Національна медична академія післядипломної освіти імені П.Л.Шупика
}

\begin{abstract}
Проведено дослідження й аналіз показників центральної гемодинаміки у 101 спортсмена високої кваліфікації, членів збірної команди України з дзюдо. Встановлені величини лабораторних показників інтегральної реовазографії, характерних для спортсменівдзюдоїстів, розділених за віком, спортивною кваліфікацією та стажем занять дзюдо.
\end{abstract}

Ключові слова: спортсмени високої кваліфікації, економізація функцій апарату кровообігу, вікові відмінності, стаж занять.

\section{СРАВНИТЕЛЬНЫЙ АНАЛИЗ ПОКАЗАТЕЛЕЙ ЦЕНТРАЛЬНОЙ ГЕМОДИНАМИКИ У СПОРТСМЕНОВ-ДЗЮДОИСТОВ ВЫСОКОЙ КВАЛИФИКАЦИИ}

\begin{abstract}
Национальная медицинская академия последипломного образования имени П. Л. Шупика
Проведено исследование и анализ показателей центральной гемодинамики у 101 спортсмена высокой квалификации, членов сборной команды Украины по дзюдо. Установлены величины лабораторных показателей интегральной реовазографии, характерных для спортсменов-дзюдоистов, разделенных по возрасту, спортивной квалифрикации и стажу занятий дзюдо.
\end{abstract}

Ключевые слова: спортсмены высокой квалификации, экономизация функций аппарата кровообращения, возрастные отличия, стаж занятий.

\section{COMPARATIVE ANALYSIS OF INDICES OF CENTRAL HEMODYNAMICS IN SPORTSMEN-JUDOISTS OF HIGH QUALIFICATION DEPENDING ON AGE, QUALIFICATION AND LENGTH OF TRAINING}

\section{M. Oleksenko}

\author{
National Medical Academy of Post-Graduate Education named after P. L. Shupyk
}

\begin{abstract}
Research and analysis of indices of central hemodynamics are conducted in 101 sportsmen of high qualification, members of combined team of Ukraine on judo. The sizes of laboratory indices of integral reovazografy are set that are peculiar for the sportsmen-judoists divided for age, sports qualification and experience of training in judo.
\end{abstract}

Key words: sportsmen of high qualification, economy of functions of vehicle of circulation of blood, age- related differences, length of training.

Вступ. Тренованість проявляється в здатності організму переносити великі фізичні навантаження, швидко й адекватно реагувати на виникаючі при цьому вимоги відповідним посиленням функцій, підтримувати досягнутий рівень діяльності організму на необхідний час (показуючи в цих умовах високу працездатність і максимальні спортивні результати), швидко відновлюватися.
При лікарському обстеженні це, тією чи іншою мірою, проявляється у відповідних змінах показників, що відображають стан різних функціональних систем, серед яких досить істотна роль належить апарату кровообігу.

Стан апарату кровообігу багато в чому лімітує працездатність, і в ряді випадків служить найбільш ранньою ознакою її погіршення. Так, наприклад, спорт-

(C) I. М. Олексенко 
смени високої кваліфікації, у ряді випадків, зберігають гарну адаптивність нервово-м'язового апарату до фізичних напруг, коли вже визначається чітке погіршення функціонального стану кровообігу.

Велике значення судинної системи у забезпеченні пристосовності організму до фізичних напруг обумовило особливий інтерес до вивчення цієї функції в лікарському контролі. Як було сказано вище, функціональний стан апарату кровообігу в значній мірі визначає рівень спортивної працездатності, у ряді випадків можна зустрітися й з певними розбіжностями. Так, наприклад, іноді високий результат може бути показаний спортсменом, коли ще не досягнуто найкращих (для нього) показників функціонального стану кровообігу, або, навпаки, коли вже є певні функціональні недоліки внаслідок перевтоми або початкових явищ перетренованості.

Дослідження функціонального стану кровообігу хоча й займають одне із провідних місць, але дозволяють оцінити загальний рівень тренованості спортсмена лише з урахуванням стану інших функціональних ланок діяльності організму. Що стосується безпосередньо дослідження апарату кровообігу, то методи, які використовуються, повинні розкривати функціональний стан різних його ланок та їх взаємозв'язок.

Останні роки характеризуються бурхливим розвитком методів дослідження функціонального стану апарату кровообігу й впровадженням в практику роботи спортивного лікаря нових методів дослідження, що зокрема, знайшло певне відображення й у теперішній роботі.

Усе це обумовлює необхідність строго індивідуальної оцінки результатів дослідження кровообігу при визначенні стану тренованості. 3 цією метою виявлені величини треба порівнювати не стільки із середніми показниками, різними таблицями й стандартами (оскільки межі фізіологічних коливань окремих ознак при оптимальному рівні тренованості у різних спортсменів досить великі), скільки з величинами, характерними саме для виду спорту, яким спортсмен займається. Саме в силу значних індивідуальних відмінностей процесу розвитку тренованості, найбільш правильно їі рівень визначати при динамічних спостереженнях, що також треба розглядати як одне із принципових положень. У той же час необхідно мати орієнтир, відштовхуючись від якого можна робити попередні висновки. Саме таким орієнтиром можуть служити типові показники центральної гемодинаміки, характерні для конкретного виду спорту.

Дослідженню діяльності серця й стану центрального кровообігу у спортсменів присвячені роботи численних авторів $[4,6]$.
Відповідно з одними дослідженнями, у спокої відбувається зменшення серцевого викиду за рахунок економізації тканинних окисних процесів під впливом тривалої м'язової роботи [1], за іншим даними, ударний і хвилинний обсяги крові у спортсменів перевищують такі показники у здорових осіб, що не займаються спортом. I, нарешті, ряд авторів не відзначає істотного впливу тренувальної діяльності на величини основних параметрів серцевої продуктивності [5]. У інших дослідженнях виявлена залежність параметрів центрального кровообігу від спрямованості тренувального процесу спортсменів [3]. Також показаний взаємозв'язок виразності функціонального стану системи кровообігу зі специфікою спортивної діяльності. Вищевикладене свідчить про те, що різні думки щодо даного питання вимагають подальшого вивчення цього напрямку.

3 боку системної гемодинаміки у спортсменів групи «витривалість» відзначалися зміни у вигляді помірної гіпотонії й брадикардії спокою, зниження МОК і підвищення загального периферійного опору [2]. Це, імовірно, пов'язано із судинним фактором іє компенсаторним у відповідь на зниження в'язкості крові.

Зниження тонусу стінок артерій, що виникає під впливом регулярних тренувань, проявляється зменшенням швидкості поширення пульсової хвилі. Показано, що при стандартному фізичному навантаженні приплив крові до працюючих м'язів спортсменів менший, ніж у нетренованих осіб. Ці дані підтверджують уявлення про економізацію функції судинної системи у спортсменів.

Характер змін показників центральної гемодинаміки при фізичних навантаженнях залежить від багатьох факторів: потужності роботи, тренованості, від стажу занять.

У літературі відсутня інформація, яка давала б досить повну інформацію про стан центральної гемодинаміки дзюдоїстів високої кваліфікації залежно від віку, стажу занять та кваліфікації.

Матеріали та методи досліджень. Обстежено 101 спортсмена, який професійно займається дзюдо, у віці від 15 до 30 років. Серед обстежених було 34 жінки та 67 чоловіків. Обстежені мали спортивну кваліфікацію: майстер спорту України - 64 спортсмени, майстер спорту міжнародного класу - 32 спортсмени та заслужений майстер спорту України - 5 спортсменів. Усі обстежувані були поділені на групи: за рівнем кваліфікації (майстер спорту України (МС), майстер спорту України міжнародного класу (МСМК), заслужений майстер спорту України (ЗМС)), за віком (до 18 років, від 18 до 30 років), та за стажем занять 
дзюдо (до 10 років, більше 10 років). Оцінку показників центральної гемодинаміки проводили за результатами дослідження інтегральної тетраполярної реовазографії (IРВГ). У кожній групі аналізували 12 лабораторних показників: частота серцевих скорочень (ЧСС), середній артеріальний тиск (АТc), ударний обсяг кровообігу (УОК), хвилинний обсяг кровообігу (ХОК), ударний індекс (УІ), серцевий індекс (СI), індекс хвилинної роботи серця (IXРC), індекс ударної роботи серця (ІУРС), питомий периферійний опір судин (ППОС), загальний периферійний опір судин (ЗПОС), об' ємна швидкість вигнання (ОШВ), потужність лівого шлуночка (ПотЛШ), витрата енергії на переміщення 1 л хв. обсягу крові (РозЕ). Для математичної обробки показників використовували сучасні статистичні методи. Статистична обробка отриманих результатів проводилася з використанням критерію Стьюдента. Вірогідність розбіжностей вважалася встановленою при $\mathrm{p}<0,05$.

Результати та їх обговорення. Діяльність спортсменів, які займаються спортивною боротьбою, проходить у варіативних конфліктних ситуаціях, що характеризуються постійною зміною просторово-часових взаємодій суперників, невизначеністю тактичних ситуацій, часовим і просторовим дефіцитом. При цьому важливо вміти реалізувати свої потенційні можливості саме тоді, коли умови двобою створюють максимум перешкод для цього. Тому інтенсивність і тип м'язової діяльності борця, величина зусиль і їх тривалість постійно змінюються. Переважно цим обумовлюється стан системи кровообігу, який відіграє провідну роль у створенні умов, що забезпечують швидку перебудову діяльності організму й мобілізацію його функціональних резервів.

Дзюдо - вид єдиноборства, у якому розвиваються й використовуються різні фізичні якості: швидкісносилова витривалість, сила, швидкість, загальна витривалість, спритність і координація. Тому вичленувати фізичну якість, яка є провідною при формуванні особливостей адаптації центральної гемодинаміки у дзюдоїстів, досить складно. Ясно тільки одне: у сутичках максимально реалізуються всі резерви енергозабезпечення м'язової роботи - алактатні, лактатні та аеробні. Це повинно накласти певний відбиток на стан центральної гемодинаміки дзюдоїстів.

Абсолютно природно, нас цікавило питання впливу рівня спортивної кваліфікації на показники центральної гемодинаміки. Ці дані представлені в таблиці 1.

Таблиця 1. Показники центральної гемодинаміки залежно від рівня кваліфікації дзюдоїстів (чоловіки і жінки разом; $\mathrm{n}=101$ )

\begin{tabular}{|c|c|c|c|}
\hline \multirow{3}{*}{ Показники центральної гемодинаміки } & \multicolumn{3}{|c|}{ Рівень кваліфікації } \\
\hline & $\mathrm{MC}$ & MCMK & $3 \mathrm{MC}$ \\
\hline & $\mathrm{M} \pm \mathrm{m}$ & $\mathrm{M} \pm \mathrm{m}$ & $\mathrm{M} \pm \mathrm{m}$ \\
\hline частота серцевих скорочень (уд/хв) & $63,0 \pm 8,7$ & $62,6 \pm 10,1$ & $57,2 \pm 6,9$ \\
\hline середній артеріальний тиск (мм рт.ст.) & $84,3 \pm 7,4$ & $84,6 \pm 7,3$ & $90,7 \pm 4,9$ \\
\hline ударний обсяг кровообігу (мл) & $83,7 \pm 16,14$ & $82,1 \pm 17,7$ & $83,0 \pm 19,6$ \\
\hline хвилинний обсяг кровообігу (мл/хв) & $5266,5 \pm 1210,9$ & $5125,2 \pm 1350,3$ & $4753,9 \pm 1317,5$ \\
\hline ударний індекс (мл/ $\left.\mathbf{M}_{2}\right)$ & $44,3 \pm 6,6$ & $41,8 \pm 7,6$ & $40,3 \pm 9,26$ \\
\hline серцевий індекс (л/хв/ $\left.\mathbf{M}_{2}\right)$ & $2,8 \pm 0,6$ & $2,6 \pm 0,5$ & $2,3 \pm 0,6$ \\
\hline індекс хвилинної роботи серця (кг х м/хв/ $/ \mathrm{M}_{2}$ ) & $3,4 \pm 0,7$ & $3,1 \pm, 07$ & $3,0 \pm 0,8$ \\
\hline індекс ударної роботи серця (г х м/M $\left.{ }_{2}\right)$ & $53,6 \pm 9,2$ & $50,4 \pm 9,8$ & $52,7 \pm 12,9$ \\
\hline питомий периферійний опір судин (дин х с х см-0,5) & $2587,4 \pm 562,1$ & $2815,0 \pm 662,5$ & $3434,0 \pm 912,2$ \\
\hline загальний периферійний опір судин (дин х с х см-0,5) & $1385,2 \pm 305,8$ & $1487,4 \pm 411,3$ & $1675,5 \pm 454,9$ \\
\hline об'ємна швидкість вигнання (мл/с) & $224,3 \pm 44,5$ & $221,3 \pm 44,4$ & $218,5 \pm 50,1$ \\
\hline потужність лівого штуночка (Вт) & $2,5 \pm 0,6$ & $2,5 \pm 0,6$ & $2,7 \pm 0,6$ \\
\hline витрата енергії на переміщення 1л хв обсягу кр & $11,2 \pm 0,9$ & $11,2 \pm 0,9$ & $12,1 \pm 0,6$ \\
\hline
\end{tabular}

На підставі даних, наведених у таблиці 1, можна сказати, що показники центральної гемодинаміки на рівні кваліфікації «МС-3МС» відрізняються між собою незначно. Помітно лише достовірне збільшення УОК у групі ЗМС, поступове збільшення УІ від МС до ЗМС, а також збільшення об' ємної швидкості вигнання і потужності лівого шлуночка в групі ЗМС.
Міра впливу на показники центральної гемодинаміки віку спортсменів і стажу занять спортом представлені в таблицях 2 і 3. Тут виявляються певні закономірності - чим більший вік борців, тим достовірно рідша у них ЧСС, вищий АТс, нижчий серцевий індекс і вищий периферійний опір судинного русла. Іншими словами, з віком прояв функції економізації 
збільшується. Що стосується стажу занять спортом, то тут подібні закономірності не виявляються. I зро- зуміло чому: стаж занять не пов'язаний безпосередньо $з$ рівнем кваліфікації спортсмена.

Таблиця 2. Залежність показників центральної гемодинаміки від віку спортсменів (чоловіки і жінки разом, $\mathrm{n}=101)$

\begin{tabular}{|c|c|c|}
\hline \multirow{2}{*}{ Показники центральної гемодинаміки } & до 18 років & 18 - 30 років \\
\hline & $\mathrm{M} \pm \mathrm{m}$ & $\mathrm{M} \pm \mathrm{m}$ \\
\hline частота серцевих скорочень (уд/хв) & $64,7 \pm 9,4$ & $61,0 \pm 9,1$ \\
\hline середній артеріальний тиск (мм рт.ст.) & $83,1 \pm 7,2$ & $85,8 \pm 7,7$ \\
\hline ударний обсяг кровообігу (мл) & $82,2 \pm 16,1$ & $83,5 \pm 17,5$ \\
\hline хвилинний обсяг кровообігу (мл/хв) & $5310,5 \pm 1223,8$ & $5072,7 \pm 1287,3$ \\
\hline ударний індекс (мл/м2) & $43,4 \pm 6,7$ & $42,5 \pm 7,4$ \\
\hline 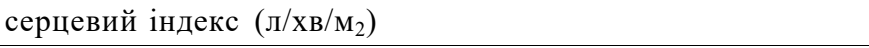 & $2,8 \pm 0,6$ & $2,6 \pm 0,5$ \\
\hline 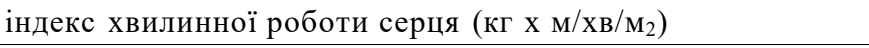 & $3,3 \pm 0,8$ & $3,2 \pm 0,7$ \\
\hline 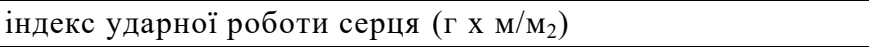 & $51,7 \pm 9,3$ & $52,2 \pm 10$ \\
\hline питомий периферійний опір судин (дин х с х см-0,5) & $2537,1 \pm 536,4$ & $2923,0 \pm 747,74$ \\
\hline загальний периферійний опір судин (дин х с х см-0,5) & $1360,2 \pm 307,4$ & $1502,6 \pm 395,2$ \\
\hline об'ємна швидкість вигнання (мл/с) & $222,3 \pm 45,3$ & $223,0 \pm 44,1$ \\
\hline потужність лівого шлуночка (Вт) & $2,5 \pm 0,6$ & $2,6 \pm 0,5$ \\
\hline витрата енергії на переміщення 1л хв. обсягу крові (Вт/л) & $11,0 \pm 0,9$ & $11,4 \pm 0,9$ \\
\hline
\end{tabular}

Таблиця 3. Залежність показників центральної гемодинаміки від стажу занять спортом (чоловіки і жінки разом, $\mathrm{n}=101$ )

\begin{tabular}{|c|c|c|}
\hline \multirow{2}{*}{ Показники центральної гемодинаміки } & до 10 років & більше 10 років \\
\hline & $\mathrm{M} \pm \mathrm{m}$ & $\mathrm{M} \pm \mathrm{m}$ \\
\hline частота серцевих скорочень (уд/хв) & $64,8 \pm 9,1$ & $61,2 \pm 9,3$ \\
\hline середній артеріальний тиск (мм рт.ст.) & $82,5 \pm 7,4$ & $86,0 \pm 7,3$ \\
\hline ударний обсяг кровообігу (мл) & $83,1 \pm 16,4$ & $83,0 \pm 17,4$ \\
\hline хвилинний обсяг кровообігу (мл/хв) & $5382,0 \pm 1243,7$ & $5057,2 \pm 1283,8$ \\
\hline ударний індекс (мл/м²) & $44,2 \pm 6,5$ & $42,2 \pm 7,5$ \\
\hline 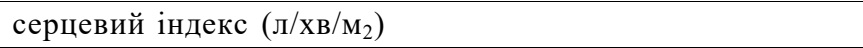 & $2,9 \pm 0,6$ & $2,6 \pm 0,5$ \\
\hline індекс хвилинної роботи серця (кг х м/хв/ $\left./ \mathrm{M}_{2}\right)$ & $3,4 \pm 0,8$ & $3,2 \pm 0,7$ \\
\hline 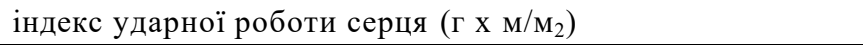 & $52,2 \pm 9,2$ & $51,9 \pm 10,1$ \\
\hline питомий периферійний опір судин (дин х с х см-0,5) & $2458,5 \pm 514,2$ & $2943,4 \pm 740,6$ \\
\hline загальний периферійний опір судин (дин х с х см-0,5) & $1320,5 \pm 277,9$ & $1514,5 \pm 407,7$ \\
\hline об'ємна швидкість вигнання (мл/с) & $223,0 \pm 45,6$ & $222,7 \pm 44,3$ \\
\hline потужність лівого шлуночка (Вт) & $2,5 \pm 0,6$ & $2,6 \pm 0,6$ \\
\hline витрата енергії на переміщення 1л хв обсягу крові (Вт/л) & $11,0 \pm 0,9$ & $11,4 \pm 0,9$ \\
\hline
\end{tabular}

В основі досягнення спортивного результату і його зростання лежать адаптаційні процеси, що відбуваються в організмі. Тренувальна і змагальна діяльність $\epsilon$ основою для їх вдосконалення.

В процесі адаптації до фізичних навантажень визначаються два етапи - тимчасова і довготривала стійка адаптація. Перехід від тимчасового етапу до стійкої довготривалої адаптації заснований на формуванні структурних змін у всіх ланках: як у морфофункціональних системах, так і в регуляторних механізмах.

Процес адаптації активно супроводжується підвищенням функціональної потужності структури і поліпшенням її функціонування. При компенсації деякі функції можуть виснажуватися і тоді функціонування організму перебігає на передпатологічному і патологічному рівнях. Такий стан дезадаптації може призвести до розвитку перевтоми, перенапруження, значного зниження працездатності і надалі - до виникнення захворювань і травм. Професіоналізм і комерціалізація в спорті, без яких зараз спорту не вижити, поставили спортсменів в умови жорсткого натиску підготовки і високих вимог до рівня функціональної підготовленості. Без оптимально збалансованого контролю за функціональною підготовкою домогтися високих результатів, освоївши величезні об'еми роботы без втрат для здоров'я, не є 
можливим. Однією з провідних систем організму в забезпеченні високої працездатності у спортсменів є серцево-судинна. Існує залежність між показниками ударного об'єму кровотоку і продуктивністю серця, а також з максимальною аеробною потужністю. 3 цих позицій систему кровообігу можна розглядати як одну з головних ланок в системі транспорту кисню при забезпеченні максимальної працездатності. Важливу роль в забезпеченні високої працездатності відіграє стан судинного тонусу. Невідповідність між фактичним периферійним опором та належним може приводити до підвищення артеріального тиску, зміни пружноеластичних властивостей судин, коронарного кровотоку тощо.

Висновки. 1. У процесі адаптації дзюдоїстів високої кваліфікації до фізичних навантажень динаміч-

\section{Література.}

1. Викулов А. Д. Кровообращение у спортсменов-пловцов / А. Д. Викулов. Ярославль, 2001. - 115 с.

2. Функциональные резервы сердечно-сосудистой системы и их оценка / Городниченко Э. А., Грицук А. Д., Чалова Л. Г., Петрова Г. В. // Российский физиологический журнал им. И. М. Сеченова. - 2004. - Т 90, № 8. - 429 с.

3. Граевская Н. Д. Спортивная медицина: Курс лекций и практические занятия: учебное пособие / Граевская Н. Д., Долматова Т. И. - М. : Советский спорт, 2004. - 304 с.

4. Земцовский Э. В. Некоторые итоги и перспективы раз- ного характеру збільшується розтяжність артерій, знижується їхній пружний опір i, в остаточному підсумку, збільшується ємність артеріального русла. Таким чином, зниження тонусу судин полегшує рух крові й сприяє зниженню енергетичних витрат серця.

2. Основним фактором регуляції ХОК є потреба в кисні, збільшення кисневотранспортної здатності крові приводить до «економізації» серцевої діяльності в спокої, що проявляється помірною брадикардією, гіпотонією, зниженням МОК, підвищенням периферійного опору.

3. Проявом економізації функції апарату кровообігу у спортсменів є адаптивні зміни швидкості кровообігу, що суттєво знижуються в спортсменів у міру росту тренованості.

вития учения А. Г. Дембо о дистрофии миокарда у спортсменов / Земцовский Э. В. // Вестн. спорт. медицины России. - 1995. - № 3-4. - С. 10-11.

5. Карпман В. Л., Белоцерковский 3. Б., Любина Б. Г. [и др.] Динамика кровообращения при минимальных физических нагрузках // Физиология человека. - 1994. - Т. 20, № 1 . C. 84.

6. Врачебный контроль при массовой физкультурно-оздоровительной работе / Мотылянская Р. Е., Ерусалимский Л. А. - М. : Физкультура и спорт, 1980. - 96 с. 